Chapter 13

\title{
Soybean Meal and The Potential for Upgrading Its Feeding Value by Enzyme Supplementation
}

\author{
D. Pettersson and K. Pontoppidan \\ Additional information is available at the end of the chapter \\ http://dx.doi.org/10.5772/ 52607
}

\section{Introduction}

Soy is a crop of tremendous importance for the food industry but also in the animal feed industry. Soybeans, as well as other oilseed crops such as rape seed (canola), sunflower and palm kernel, are grown primarily for the production of vegetable oil for human consumption but the by-products after oil extraction are of similar importance as feed ingredients. Meals from these crops are obtained after the extraction of the vegetable oil from the seed. In addition, considerable amounts of cottonseed meal (a by-product of the cotton fibre production) are also available for animal feed. Soybean meal (SBM), the by-product after oil extraction of soybeans has become increasingly important as a feed component and is used in variable amounts in the feeding of all species in animal production, even to some extent in the feeding of farmed fish. On a global scale SBM is dominating the market for protein meals primarily due to the high content of good quality protein, making SBM an excellent ingredient in feed formulations. SBM is particularly important for poultry production, constituting approximately $30-40 \%$ of a standard soy/maize diet, since broilers and layers require a high proportion of protein in their feed. It is generally estimated that approximately $46 \%$ of all SBM produced for animal feed is used in poultry diets (broilers, layers and turkeys), while another $25 \%$ is used for feeding pigs. In the US approximately $50 \%$ of the SBM is used for poultry, $25 \%$ for swine and $12 \%$ for beef cattle. Although US is the largest producer of soybeans, Argentina is by far the largest exporter of SBM followed by Brazil and US. With very limited own production of soy the EU is one of the leading markets for import of SBM. [1]

Over the last 5 years the price for SBM has been increasing, and this trend is expected to continue in the future. Hence, with protein already being the second most expensive ingredient in e.g. poultry diets, there is a need to either replace SBM with other and cheaper pro- 
tein ingredients in the diets or to increase the utilization of SBM nutrients e.g. by the use of enzymes.

\section{Composition and nutritive value of soybean meal}

SBM consists primarily of protein and carbohydrates in the form of indigestible neutral and acidic non-starch polysaccharides (NSP) as well as low molecular weight sugars (Table 1).

Due to the low content of easily available carbohydrates, and a high content of NSP belonging to the indigestible dietary fibre fraction [2] the apparent metabolisable energy value (AME) of SBM is low for broiler chickens and estimated to only about $9.5 \mathrm{MJ} / \mathrm{kg}$ fresh weight, while in growing pigs that, as opposed to poultry, have a high capacity for hind gut fermentation of the indigestible carbohydrate fraction, the AME value may be around 14.5 $\mathrm{MJ} / \mathrm{kg}$ fresh weight [3].

\begin{tabular}{lcc}
\hline & \multicolumn{2}{c}{ Range (g/kg dry matter) } \\
\hline Component & Low & High \\
\hline Crude protein & 490 & 540 \\
\hline Starch & 0 & 27 \\
\hline Crude fat & 17 & 21 \\
\hline Low molecular weight sugars & 5 & 8 \\
\hline Mono saccharides & 55 & 81 \\
\hline Sucrose & 53 & 67 \\
\hline Raffinose series & & 5 \\
\hline Neutral non starch polysaccharides & 3.7 & 3.1 \\
\hline Rhamnose & 2.9 & 25 \\
\hline Fucose & 22 & 18 \\
\hline Arabinose & 15 & 13 \\
\hline Xylose & 9 & 40 \\
\hline Mannose & 37 & 59 \\
\hline Galactose & 50 & 41 \\
\hline Glucose & 39 & \\
\hline Ucidic non starch polysaccharides & 95 & \\
\hline
\end{tabular}

Table 1. Typical soybean meal gross chemical composition. ( $\mathrm{g} / \mathrm{kg}$ dry matter), compiled from literature, for crude protein, starch, crude fat and low molecular weight sugars, while the non-starch polysaccharide composition of a selection $(n=6)$ of soybean meals were analysed at Novozymes A/S according to Theander et al. [4]. Data compiled from $[2,3]$ as well as from internal analysis of neutral and acidic non starch polysaccharide constituents. 
The composition of SBM may vary depending on the country of origin of the soybean, the cultivar, the processing and the inevitable year to year variation in growing conditions. Still most feeding tables contains very little, if any, information about the variability of e.g. amino acids (AA) and digestibility that may be expected although the data presented typically is based on several hundred samples collected over several years. Neither is the indigestible dietary fibre fraction well described in feed tables and at best values for neutral detergent and acid detergent fibre are provided.

\subsection{Protein}

Plants cultivated for their protein content are typically classified as angiosperms and belong to a number of different botanical families. Beans, peas, lupins and soybeans are all members of the leguminosae family while rape seed belong to the cruciferae family, sunflower and safflower are members of the compositae family and cotton belongs to the malvaceae [5]. On average the content of $\mathrm{CP}$ in the common raw oilseeds such as soybean, sunflower and rape seed ranges from $20-40 \%$. Due to the various processing steps and the subsequent concentration of the protein-containing fraction by solvent extraction, the average $\mathrm{CP}$ content of oilseed meals varies from $32 \%$ in sunflower meal to over $50 \%$ in some SBM [6]. $\mathrm{SBM}$ is used in feed rations for monogastric animals mainly due to the high protein content and also because of the superior AA profile compared to other plant protein products used as diet ingredients [3]. Poultry and swine diets are generally formulated based on AME and the level of CP. SBM has a high content of lysine, which makes it a good ingredient in poultry and swine diets as both of these species has a high requirement for this essential amino acid.

The CP fraction of SBM is made up of around $80 \%$ storage proteins in the form of glycenin and $\beta$-conglycenin, approximately $5 \%$ is represented as various anti nutritional factors (ANFs) and the remaining $15 \%$ consists of other proteins. Most tables on nutrient composition of feedstuffs such as e.g. the NRC [7] operates with two types of SBM based on the crude protein CP content. One is the regular SBM with approximately $44 \% \mathrm{CP}$, where a fraction of the hulls has been added back into the meal, and the other is dehulled SBM with approximately $48 \% \mathrm{CP}$. The feed compound industry principally assumes that the digestible AA content of SBM per unit of protein is constant; disrespecting that variability may occur due to e.g. genotype, origin, processing and storage conditions [8-10]. The variability in SBMs has been nicely demonstrated by de Coca-Sinova et al. [10] who evaluated six SBMs from different origins and found considerable variation in the chemical composition and protein quality which translated into differences in AA digestibility in broilers, so that SBM with higher levels of CP and lower levels of trypsin inhibitor activity showed higher AA digestibility.

\subsection{Carbohydrates}

For broiler chickens vegetable protein sources typically have a low metabolisable energy content compared to cereals, due to a lower starch content and a higher content of indigestible NSP, which are part of the dietary fibre fraction (Table 1). 
The structural features of the common vegetable protein sources are more complex than that of cereals but their cell walls still contains cellulose and hemicelluloses but in addition also high amounts of rhamnogalacturonans, assigned to the pectic polysaccharides. Quantification of the pectic fraction is not straightforward due to a more complex structure and since extraction procedures used for the analysis often causes an overestimation and the literature data may differ.

It is notable that AME table values and AME calculated on the content of $\mathrm{CP}$, crude fat, starch and sucrose (Table 2) are quite similar for meals from soybean and sunflower while in meals from rape seed and cotton seed the discrepancy is 1.7 and $2.3 \mathrm{MJ} / \mathrm{kg}$, respectively. The amount of pectin (61 g uronic acids/ $\mathrm{kg}$ dry matter) and fibre matrix structure of rape seed most likely increases the water holding capacity of this raw material resulting in a poor nutrient availability for monogastric animals and in addition ANFs may reduce the energetic value. In cotton seed similar effects may be at play although the pectin content is quite similar to that of SBM (about $45 \mathrm{~g} / \mathrm{kg}$ dry matter), while the ANFs are different and the cellulose content is considerably higher.

\begin{tabular}{|c|c|c|c|c|}
\hline & Soybean & Rape seed & Sunflower & Cotton seed \\
\hline Crude protein & 450 & 337 & 426 & 426 \\
\hline Crude fat & 10 & 23 & 29 & 29 \\
\hline Starch & 5 & 0 & 0 & 0 \\
\hline Sucrose & 70 & 58 & 33 & 16 \\
\hline Oligo, di and mono-saccharides, except sucrose & 67 & 24 & 23 & 56 \\
\hline Cellulose & 62 & 52 & 89 & 92 \\
\hline Total dietary fibre & 233 & 354 & 326 & 340 \\
\hline \multicolumn{5}{|l|}{ Apparent metabolisable energy (AME) in broilers } \\
\hline Table values AME (MJ/kg) & 9.5 & 5.9 & 6.2 & 6.3 \\
\hline Calculated AME (MJ/kg) ${ }^{\mathrm{b}}$ & 9.3 & 7.6 & 6.9 & 8.6 \\
\hline
\end{tabular}

Table 2. Average chemical composition. ( $\mathrm{g} / \mathrm{kg}$ fresh weight) of solvent extracted meal from soybean, rape seed, sunflower and cotton seed. Table compiled from [2,3]. aTable values from [3]. bValues based on crude protein, crude fat, starch and sucrose.

Plant cell walls are divided in primary and secondary walls and their composition will differ according to their stage of development (maturity). Primary cell walls are flexible and surround cells in growth and elongation whereas secondary walls surround cells in which growth has ceased. The secondary walls are lignified and thereby rigid. The primary cell wall is synthesized during cell expansion at the first stages of development and is composed of cellulose, hemicelluloses, pectic polysaccharides and many proteins (Table 3). 
Cell walls are classified as Type I cell walls, which are generally the most common in the plant kingdom, or as Type II which is typical for grasses. The non-cellulosic polysaccharides of Type I cell walls are xyloglucans and about $35 \%$ of the cell wall mass are pectins. Type I cell walls are found in all dicotyledons, the non-graminaceous monocotyledons, and gymnosperms. Type II walls have a low pectin and xyloglucan content and a high arabinoxylan content. Type II walls also contain mixed linked $\beta$-D-glucan and possess ester linked ferulic bridges in the xylan, which have not as yet been found in Type I walls [11].

In soybeans and other dicotelydons the pectin fraction consists of rhamnogalacturonans. The rhamnogalacturonan I consists of a main chain of galacturonic acid and rhamnose. Attached to this structure there are side chains of galactose and arabinose residues. There are also xylose and rhamnose side chains present as well as xylo-galacturonans. In addition traces of mannose polysaccharides may be found that possibly origin from an incomplete removal of the hull fraction from the meal [12].

In the cotelydons approximately $30 \%$ of the NSP belong to the pectin fraction while in the hulls about $80-90 \%$ of the non-starch polysaccharides are of pectic origin. The galactose content of SBM is generally higher than in other oilseed meals and is highly associated with the rhamnogalacturonans. This is not the case for rape seed meal, sunflower meal and cotton seed meal [13] where arabinans and arabinogalactans constitute the most important side chains. Since the NSP are indigestible by the endogenous enzymatic systems in the small intestine they can only be utilised through hind-gut fermentation, thereby providing short chain fatty acids that may be absorbed in the hind gut and utilised as an energy source by the animal. As a consequence the AME content of all oilseed meals is low for broiler chickens that have a limited capacity for hind gut fermentation, while it is higher for pigs [14].

The dietary fibre fraction is composed of different polysaccharide structures and their molecular structure and incorporation into the cell wall matrix determines their solubility characteristics. A high solubility favours fermentation and even poultry may to some extent ferment soluble NSP [15,16].

The principal hemicelluloses found in dicotelydons including soybeans are xyloglucans (Table 3) consisting of a glucose back bone with xylose side chains linked to the carbon 6 of the glucose residues in the back bone chain. It is a well acknowledged hypothesis that primary and secondary cell walls in dicotelydons are constructed in different ways. In the primary cell wall cellulose and xyloglucans interact in a network consisting of cellulose which is coated with a monolayer of xyloglucans. The secondary cell wall is composed of pectins, but not of the homogalacturonan type that is found in fruit and berries. In soybean the pectic polysaccharides are xylogalacturonans with a backbone of $\alpha$-(1-4)-galacturonan residues and to this xylose residues are linked in $\beta-(1-3)$ position. The xylogalacturonans are associated with regions that consist of rhamnogalacturonans type I and II, with a higher degree of branching in the type II $[18,19]$. Together with the xylogalacturonans the rhamnogalacturonan I and its side chains consisting of arabinans and arabinogalactans makes up the main part of the pectic substances [20]. 


\begin{tabular}{|c|c|c|c|}
\hline \multirow[t]{2}{*}{ Component } & & \multicolumn{2}{|c|}{ Approximate composition (\%) } \\
\hline & & Primary cell walls & Secondary cell walls \\
\hline Cellulose & & 30 & $45-50$ \\
\hline \multirow[t]{4}{*}{ Hemicellulose } & Xyloglucan & 25 & \multirow{2}{*}{25} \\
\hline & Xylans & 5 & \\
\hline & B-D-glucans & nd & nd \\
\hline & Glucomannan & nd & nd \\
\hline \multirow[t]{3}{*}{ Pectins } & Homogalacturonans & 15 & \multirow{3}{*}{0.1} \\
\hline & Rhamnogalacturonan I & 15 & \\
\hline & Rhamnogalacturonan II & 5 & \\
\hline Glycoproteins & Arabinogalactanprotein & Variable & nd \\
\hline \multirow[t]{3}{*}{ Phenolics } & Extensin & $<5$ & nd \\
\hline & Lignin & nd & 20 \\
\hline & Phenolic acid & 0.3 & nd \\
\hline
\end{tabular}

Table 3. Major polymers of the growing and mature plant cell walls in dicotelydons. Table compiled from [17].

\subsection{Anti nutritional factors}

The occurrence and amount of ANFs and their effect on protein and energy utilisation limits the inclusion of vegetable proteins in diets for pigs and poultry. In general, ANFs among legume species are similar, however the actual amounts of ANFs varies widely between different species and cultivars [21]. The main ANFs include protease inhibitors, lectins, tannins, phytic acid and indigestible carbohydrates. In addition, lupins contain considerable amounts of alkaloids and lima beans contain increased amounts of cyanogens as their dominant ANFs [22,23]. Oilseeds, and subsequently oilseed meals, have more specific ANFs depending on the actual species. Rapeseed meal contains glucosinolates and soybean is particularly high in trypsin and chymotrypsin inhibitors while cottonseed meal contains gossypol [24]. Based on what is commonly known in the feed industry and academia it may be assumed that the content of ANFs may differ depending on growing conditions and, especially, the heat processing of the feed ingredients.

The best characterized ANFs of soybean are protease inhibitors, lectins and phytate.

The Kunitz inhibitor (KSTI) together with the Bowman-Birk inhibitor (BBI) are the most abundant protease inhibitors in soybeans, and are commonly referred to as trypsin inhibitors even though they may also inhibit e.g. chymotrypsin and other proteases belonging to the serine family. The mechanism of trypsin inhibitors is to bind to the active site of the protease and thereby cause inactivation of the enzyme, which then cannot proceed to degrade 
protein. When the level of protease activity in the gut is depressed the pancreas responds in a compensatory fashion by producing more of the digestive enzymes. In some species this has been shown to be related to an enlargement of the pancreas [25,26]. When animals are fed SBM with a high level of protease inhibitors the digestive proteases trypsin and chymotrypsin are inactivated leading to impaired animal performance. This has been exemplified e.g. by Sklan et al. [27] who showed that chicks fed raw soy had significantly reduced bodyweight gain compared to a control group fed heated soy. Furthermore, the chicks fed the raw soy had increased pancreas weight and reduced trypsin activity in the small intestine.

Lectins are carbohydrate binding proteins generally considered to have an anti nutritional effect $[28,29]$. This has been exemplified e.g. by Schulze et al. who showed that inclusion of purified soybean lectin into a pig diet increased the amount of dry matter, nitrogen $(\mathrm{N})$ and AA passing into the terminal ileum [30].

Phytic acid, also commonly referred to as phytate, is a well described anti nutritional factor that under physiological $\mathrm{pH}$ conditions binds minerals and protein thereby preventing utilization of these nutrients by the animal [31,32].

Furthermore, the high molecular weight soy proteins glycenin and $\beta$-conglycenin act as potential antigenic factors leading to the formation of serum antibodies in particular in young animals, e.g. early-weaned piglets [33].

\subsection{Impact of processing on nutritive value}

As opposed to the cereal grains the composition and nutritive value of oilseed meals for animal feed not only depends on the cultivar, the climatic condition and level of fertilisation, but is also influenced by the processing conditions during the oil extraction procedure. Oilseed meals are generally obtained after a pre-press solvent extraction process. The combined effects of seed preparation, de-hulling pre-conditioning, cooking and solvent extraction will determine the nutritive value of the meal.

The processing of soybeans (Figure 1) and in particular the final heating step (toasting) is critical to the quality of the resulting SBM. The initial processing of soybeans includes cleaning, drying and cracking of the beans to remove the hulls. The dehulled soybeans are the raw material for production of full fat soybean meal which may or may not be heat treated to inactivate enzymes. When processing regular SBM the dehulled beans are conditioned at $65-70^{\circ} \mathrm{C}$ followed by flaking, which prepares the beans for oil extraction. The oil is usually extracted using a solvent such as hexane. Finally the resulting cake is treated in a toaster in order to remove the solvent and to heat the meal sufficiently to optimize its nutritional value. In this process control of the processing conditions such as temperature, moisture, pressure and processing time is highly important to maintain a high solubility of the SBM product. [34] After toasting a fraction of the hulls will often be transferred back into the meal to produce SBMs with different protein contents. 


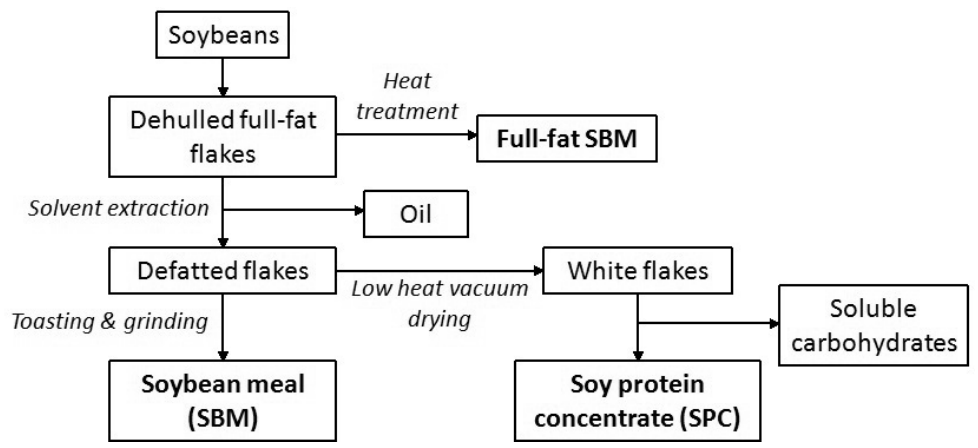

Figure 1. Overview of the processing of soybeans to obtain soybean meal (SBM), full fat SBM or Soy protein concentrate (SPC).

As mentioned earlier the nutritional value of SBM is limited by the presence of several ANFs interfering with feed intake and metabolism. ANFs are concentrated in large amounts in the hull fractions of oilseeds and de-hulling will consequently reduce the level of these substances in the meal. Furthermore, heat processing of the SBM acts to destroy the heat sensible ANFs such as protease inhibitors and lectins. However, in case SBM is heated excessively the occurrence of Maillard reaction will increase. Maillard reactions occur between the amino group of the amino acids and the reducing sugars eventually leading to a decrease in energy and amino acid digestibility [35]. Hence, the conditions applied during processing to ensure a high quality of the protein fraction are a compromise between sufficiently inactivating the ANFs and avoiding destruction of essential available nutrients.

An important problem faced by the feed industry is the lack of good techniques to correctly evaluate the quality of commercial SBMs. The available methods, of which determination of the protein dispersibility index (PDI) [36], $\mathrm{KOH}$ protein solubility $[37,38]$ and urease activity [39] are the most commonly used, are based on changes in the physical and chemical properties of SBM occurring during heat treatment, and have shown not to be fully reliable $[40,41]$. Another means to estimate SBM quality is the determination of trypsin inhibitor content, but this method is tedious and also shows inconsistency [43].

The defatted soy flakes can also be processed to obtain a soy protein concentrate (SPC), which is a higher value protein product compared to SBM. This processing takes place by removing the solvent (e.g. hexane) by low heat vacuum drying and then removing the soluble carbohydrates yielding a final product with $\sim 90 \%$ protein [43]. SPC has a much lower level of ANFs than SBM and is therefore particularly well suited for young animals that do not tolerate normal SBM well, e.g. piglets. Lately the use of SPC in salmon and trout diets to replace fishmeal is also being evaluated [43]. 


\section{Enzymes for improving the nutritive value of soybean meal}

The use of exogenous microbial enzymes is today a mature concept in the animal feed industry and is used on a routine basis to improve the nutritive value of feed ingredients. The logical implication of improving the nutrient utilization is a reduced amount of nutrients in manure, which is highly beneficial for the environment especially in areas with intense animal production. The environmental benefits of using enzymes in animal diets has been exemplified in a series of published life cycle assessment studies investigating the effects of xylanase [44], phytase [45] and protease [46] when used in either pig or poultry diets. These studies together demonstrate the huge potential impacts on global warming, eutrofication and acidification that can be achieved by employing feed enzymes in animal diets to improve the utilization of nutrients.

\subsection{Protein degrading enzymes}

With protein being a quite expensive ingredient in animal diets, improving the nutritional value of the SBM protein fraction is an obvious target for enzyme application. The apparent ileal digestibility (AID) of CP in SBM is typically around $80-85 \%$, but lower values have also been reported. In an investigation of 6 different SBMs originating from South America, US and Spain the AID of CP and AA was shown to vary considerably between the batches with the US SBM having the highest digestibility value $(82.3 \%)$ followed closely by the Spanish SBM (81.8\%) and with the South American SBM's having considerably lower (75.2-76.8\%) digestibility values [10]. These results serve to demonstrate the impact of differences in SBM quality when formulating diets to achieve the necessary protein content and AA availability. Since it is both difficult and laborious to investigate SBM quality, in practice diets are often formulated to contain higher levels of nutrients than required, thereby providing a safety margin.

Early attempts to improve the nutritive value of SBM for pigs and poultry aimed at pretreating SBM in the presence of a protease to increase protein solubilisation and obtain a decrease in antigenicity. Using this approach it was demonstrated that treating SBM with either an acidic protease or an alkaline protease increased the amount of soluble $\alpha$-amino $\mathrm{N}$ concentration and reduced the antigenic protein concentration, more so with the acidic protease compared to the alkaline protease treated SBM [47]. Furthermore, feeding studies in piglets [47] and broilers [48] showed that feeding SBM treated with the acidic protease instead of the non-treated SBM as part of a cereal-based diet led to performance improvements in both species as well as to improved $\mathrm{N}$ digestibility and reduced serum antisoya antibodies in broilers. In contrast feeding SBM treated with the alkaline protease reduced performance in piglets [47], and even though Ghazi et al. did observe reductions in chick serum antisoya antibodies upon feeding SBM treated with alkaline protease only the acid protease treated SBM resulted in a positive effect on performance and digestibility parameters [48]. Differences in digestibility may occur either directly or indirectly due to hydrolysis of ANFs interfering with the digestive process. Protease treatment in above studies did not influence the already low level of trypsin inhibitor and lectin. Hence, it was 
concluded that the increase in performance and $\mathrm{N}$ digestibility by treatment with the acidic protease was a result of general improvement in digestion of SBM protein rather than inactivation of ANFs [47,48].

More recent studies have shown that direct addition of a pure protease from Nocardiopsis prasina can lead to significant increases in $\mathrm{CP}$ and AA digestibility in broilers fed SBM or full fat SBM $[49,50]$. It was concluded that AA utilization was on average improved by about 5 $\%$ in SBM and $6 \%$ in full fat SBM. Furthermore, the same protease has been demonstrated in several studies to have a positive impact on growth performance and $\mathrm{N}$ digestibility of broilers fed complete corn-SBM based diets $[51,52,53]$. The efficiency of the Nocardiopsis prasina protease to improve digestion of the SBM protein fraction is supported by internal laboratory studies at Novozymes A/S demonstrating the ability of the protease to improve protein hydrolysis in different SBM batches as well as in full fat SBM (Figure 2).

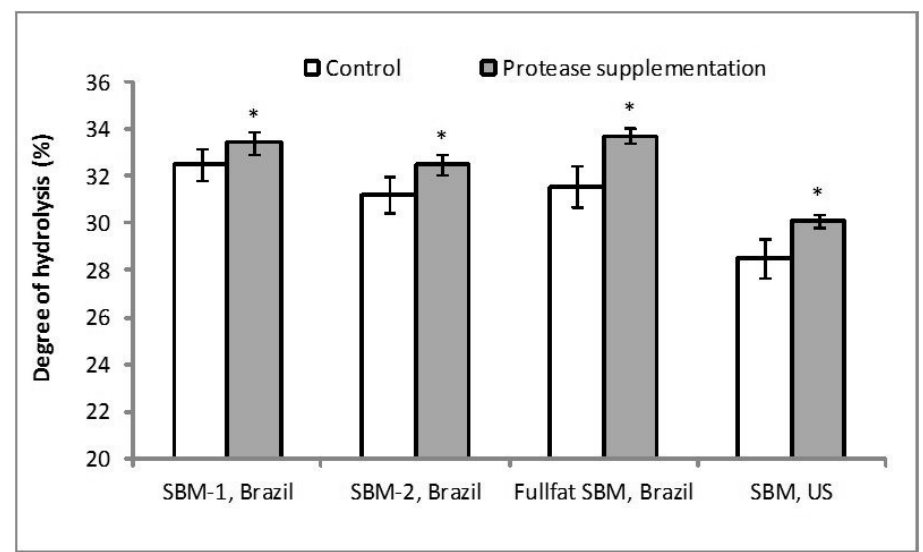

Figure 2. Increase in degree of protein hydrolysis $(\mathrm{DH}, \%)$ by a pure protease from Nocardiopsis prasina dosed at 100 mg purified enzyme protein per $\mathrm{kg}$ of SBM $(n=5)$. The Various SBM batches were incubated in an in vitro digestion system and protease effect on top of endogenous enzymes (pepsin and pancreatic enzymes) was analysed as increase in $\mathrm{DH}$ (method published in [53]). Error bars indicate standard deviation and asterisks indicate a significant impact of the protease ( $\mathrm{P}<0.05$; Tukey HSD test). Unpublished data, Novozymes A/S.

The way by which a protease increases hydrolysis and digestion of the SBM protein fraction may be related to both general hydrolysis of the SBM proteins and to degradation of various ANFs present in SBM. A general hydrolysis of SBM protein would presumably increase the availability of the protein for further hydrolysis and absorption in the gastro intestinal tract. On the other hand, degradation of ANFs will improve the natural digestion and utilization of protein as the adverse effects of the ANFs are reduced.

In this context internal studies have shown that the Nocardiopsis prasina protease is capable of degrading various anti nutritional proteins from soybean. As exemplified in Figure 5 the protease efficiently degraded both the Kunitz inhibitor (KSTI) and lectin (Figure 3), leaving only $10-20 \%$ KSTI and around $15 \%$ lectin intact, while purified porcine trypsin and chymo- 
trypsin could not degrade these proteins to nearly the same extent. The ability of a feed protease to degrade ANFs presents an interesting possibility to alleviate the negative impacts of including raw soy or under processed SBM in e.g. poultry or swine diets.

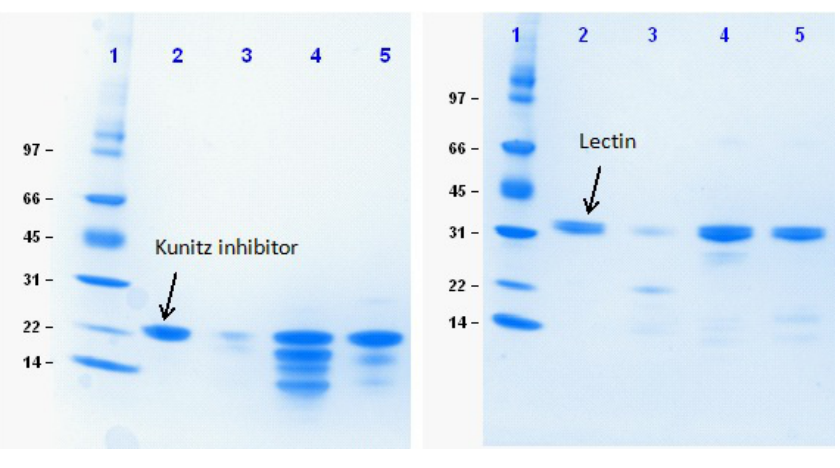

Figure 3. Degradation of purified Kunitz trypsin inhibitor (left) and lectin (right) both from Glycine max by purified proteases as analysed by SDS-page. Lane 1: low molecular weight marker (kDa), lane 2: no protease, lane 3: Nocardiopsis prasina protease, lane 4: porcine trypsin, lane 5: porcine chymotrypsin. Inhibitors (purchased from Sigma-Aldrich) and proteases were incubated in a 10:1 ratio on mg protein basis for 2 hours at $37^{\circ} \mathrm{C}$, after incubation protein was precipitated with TCA, re-suspended in SDS-page sample buffer and analysed by gel electrophoresis. Unpublished data, Novozymes A/S.

\subsection{Carbohydrate degrading enzymes}

For degradation of the major dietary fibre constituents of importance in cereals there are many enzyme products available on the market and approved by the EU authorities based on proven efficacy in animal trials. The beneficial effects on animal performance, especially in broiler chickens, are assumed to be caused by a combination of depolymerisation of viscous arabinoxylans and a degradation of the indigestible cell wall. The resulting viscosity reduction improves nutrient absorption and the degradation of the cell walls improves the liberation of nutrients (e.g. starch and protein) enclosed by the indigestible cell walls $[54,55]$. This effect is commonly referred to as the cage effect. For oil seed meals the expected outcome of degradation of the cell walls is less obvious since they generally do not have an intact cell wall architecture due to extensive processing and thereby there is no cage effect. Still the water holding capacity of the material could be reduced and this could have a positive influence on nutrient absorption. In addition liberation of galactose could provide additional energy, at least from SBM. In rape seed, which has less galactan side chains associated with the pectin matrix, an anticipated energy benefit would be limited. Another possibility would be to degrade the oligosaccharides of the raffinose series and the most common attempts to improve the nutritive value of SBM have targeted these. A successful degradation of this fraction could release galactose, and also sucrose, which is the molecule from which the raffinose series is built. Raffinose, stachyose and verbascose contains (1-6)- $\alpha$-galactopyranosyl units with variable chain lengths of which stachyose (two galactose units in the chain linked to sucrose) is the pre-dominant in SBM. The oligosaccharides of the raffinose series 
can be broken down using an $\alpha$-galactosidase that liberates the galactose from the sucrose molecule. This is a straightforward enzymatic application that has been tested in vitro showing that $\alpha$-galactosidase can degrade the oligosaccharides of the raffinose series in SBM $[56,57]$. Internal trials at Novozymes A/S (Figure 4) has indicated a large variability in the efficacy of $\alpha$-galactosidase when exposed to the conditions prevailing in the upper gastro intestinal tract simulated in an in vitro digestion system. The average release of galactose from the raffinose series was about $6.7 \mathrm{mg} / \mathrm{g}$ diet and since maize only contains minor amounts of galactose the main part of the galactose originated from the SBM and about $16 \mathrm{~g}$ of galactose could theoretically be released from $1 \mathrm{~kg}$ of SBM, corresponding to a potential AME value increase of approximately $0.3 \mathrm{MJ} / \mathrm{kg}$ SBM. The in vitro model does not provide information of any additional beneficial effects of degrading the raffinose series. Still the application is of interest since the oligosaccharides of the raffinose series are indigestible but readily fermented and this may cause digestive disturbances with gas production and rapid digesta passage rates in poultry $[58,59]$. The removal of these oligosaccharides by ethanol extraction has been shown to increase the metabolisable energy content as well as the transit time in adult roosters [60]. However, this procedure alters the general composition of the SBM by also extracting other ethanol soluble components, resulting in a meal with higher $\mathrm{CP}$ content and improved nutritive value. When using oligosaccharide or non-starch polysaccharide degrading enzymes the SBM composition is not altered and the effects observed can be attributed to the enzyme per se. Trials in pigs have generated high digestibilities in the small intestine even without $\alpha$-galactosidase supplementation [61], while poultry data indicate a positive enzyme effect on the digestion of the raffinose series but not on performance [62]. Based on these and similar data it may be concluded that performance data are not strong enough to justify, from an economical point of view, the additional supplementation of this enzyme in broiler chicken diets that already may contain xylanases and phytases.

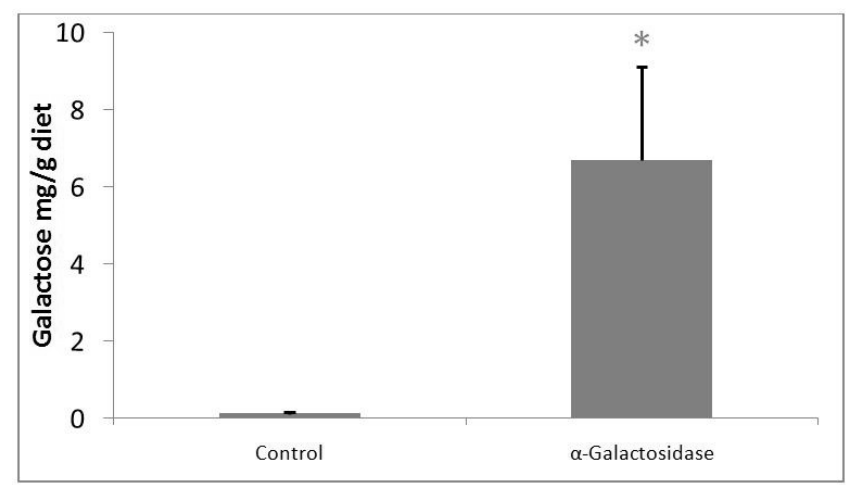

Figure 4. Release $(\mathrm{mg} / \mathrm{g})$ of galactose by a-galactosidase from 5 replicates of a model diet containing $600 \mathrm{~g}$ maize and $400 \mathrm{~g}$ soybean meal per $\mathrm{kg}$ and incubated at $40^{\circ} \mathrm{C}$ in an in vitro system mimicking the stomach (pH $3 \pm 0.2$ and $3000 \mathrm{U}$ of pepsin/g diet) and small intestine $(\mathrm{pH} 7 \pm 0.2$ and $8 \mathrm{mg} / \mathrm{g}$ diet of pancreatin) for a total period of $6 \mathrm{~h}$. Standard deviations are indicated by error bars and asterisks indicate a statistically significant difference $(P<0.05 ;$ Tukey HSD test) compared to blank. Unpublished data, Novozymes A/S. 
The use of galactanase has shown that also the galactose side chains of the rhamnogalacuronans may to some extent be degraded [63]. As opposed to many other feed enzyme products on the market a classical wild type fermentation product of Aspergillus aculeatus (RONO$\mathrm{ZYME}^{\circledR}$ VP, DSM Nutritional Products, Basel, Switzerland), is able to significantly impact the NSP fraction of SBM. In an in vitro trial comparing this product with a selection of feed enzymes developed for targeting the cereal ingredients in animal feed the preparations were dosed at 100 times the commercial recommendation in a buffer system. After incubation the solubilised material was removed by centrifugation and the pellets containing the residual insoluble NSP were analysed according to Theander et al. [4]. The effect of the A. aculeatus product on NSP containing arabinose, although not statistically significant from the control, was the highest compared to all other enzyme treatments with a reduction of about $6.5 \%$ (Figure 5). In addition the A. aculeatus product gave a significant reduction $(\mathrm{P}<0.05)$ of galactose by 9.6 $\%$ compared to the control treatment, whereas the other enzyme treatments did not provide a reduction. The residual glucose content was significantly lower for the A. aculeatus product and the blend product compared to the control, 22 and $13 \%$, respectively, and these effects were statistically significant compared to all other treatments (Figure 3). The results indicate that in order to degrade the complex cell wall matrix of SBM several enzymatic activities are required at a high activity level and these are not generally found in single commercial products developed for targeting type II cereal cell walls. It is also obvious that only one single enzymatic activity is not enough to provide a sufficient degradation of the different polysaccharide structures of importance (Table 3).

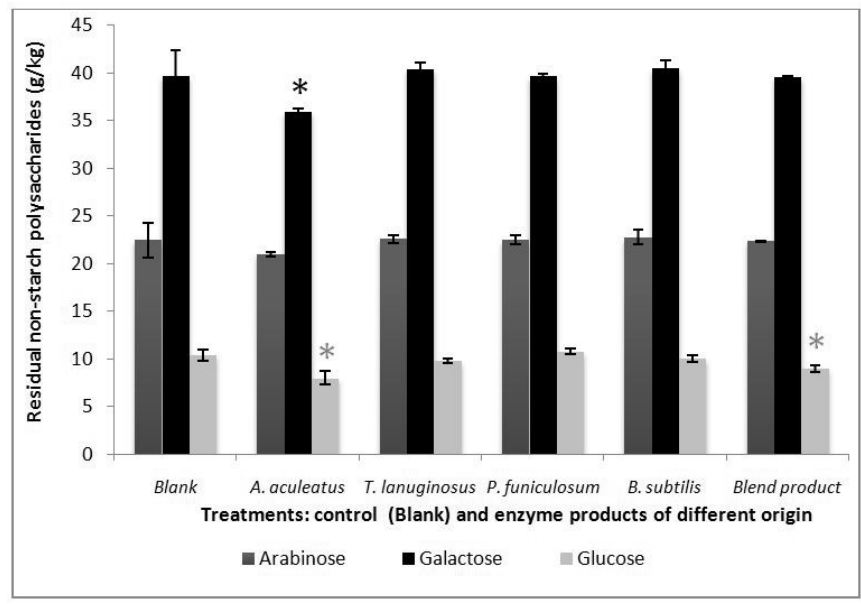

Figure 5. Residual insoluble content $(\mathrm{g} / \mathrm{kg})$ of arabinose, galactose and glucose non-starch polysaccharide residues in a soybean meal after incubation at $40^{\circ} \mathrm{C}$ in an acetate buffer $(0.1 \mathrm{M} \mathrm{pH} 5.0)$ for 4 hours and with enzymes dosed at 100 times the commercial recommendation. The products used were the Aspergillus aculeatus wild type fermentation or different products containing only xylanase activity derived from Thermomyces lanuginosus or mainly xylanase and B-glucanase activity in products derived from Penicillium funiculosum or Bacillus subtilis and a commercial blend product containing xylanase, B-glucanase and a-amylase activities. Standard deviations are indicated by error bars and asterisks indicate a statistically significant difference $(P<0.05$; Tukey HSD test) compared to blank. Unpublished data, Novozymes A/S. 


\subsection{Phytic acid degrading enzymes}

The content of phytic acid in SBM is typically around 1.3-1.4 \% of dry matter and constituting around $50 \%$ of the total phosphorus pool [64-66]. Phytic acid is not absorbed in the gastro intestinal tract, but may be degraded by a phytase to render the phosphorus free and available for absorption. Phytases are enzymes that cleave of the phosphate groups from the inositol ring of phytic acid, thereby rendering free phosphorus to be utilized by the animal and also lowering the anti nutritional effect of phytic acid on mineral and protein availability. Phytase activity is present in most seeds but the activity in oilseed meals including SBM is relatively low [65], hence degradation of SBM phytic acid necessitates the presence of phytase either from cereals in the diet or from a microbial phytase source. Since a large part of the feed for poultry and swine is treated at high temperatures e.g. in a pelleting process in order to sanitize the feed from Salmonella infections etc., cereal phytases are often inactivated in the final feed (e.g. [67]). Hence, the use of microbial phytases in feed formulation is extensive.

\begin{tabular}{ll}
\hline Feedstuff & Residual phytic acid (\%) \\
\hline Wheat & $21.5 \pm 1.3 \mathrm{ab}$ \\
\hline Maize & $24.5 \pm 1.3 \mathrm{~b}$ \\
\hline Barley & $21.3 \pm 1.3 \mathrm{ab}$ \\
\hline Soybean meal & $47.9 \pm 1.3 \mathrm{c}$ \\
\hline Rapeseed meal & $21.3 \pm 1.3 \mathrm{ab}$ \\
\hline Soybean meal-maize blend & $17.2 \pm 1.5 \mathrm{a}$ \\
\hline
\end{tabular}

Table 4. abc: Different letters indicate significant differences $(P<0.05)$, tested by Tukey HSD. Residual phytic acid (\%) after incubation of feedstuffs with a commercial phytase (RONOZYME* HiPhos, DSM Nutritional Products, Basel, Switzerland) for 30 minutes $\left(\mathrm{pH}_{4}, 40^{\circ} \mathrm{C}\right)$. All feedstuffs were heat treated and additional calcium $\left(6 \mathrm{~g} \mathrm{~kg}^{-1} \mathrm{dry} \mathrm{matter}\right.$ was added. Values are representative of the sum of inositol hexaphosphate and inositol pentaphosphate. [68]

Degradation of phytic acid in SBM has been demonstrated e.g. by Brejnholt et al. [68] showing a $50 \%$ degradation of phytic acid upon incubation of SBM with a bacterial phytase at $\mathrm{pH} 4$ (30 minutes, $40^{\circ} \mathrm{C}$ ). Interestingly this study indicated that it was more difficult to degrade phytic acid in SBM compared to phytic acid in cereal meals and rape seed meal (Table 4). This difference might be related to the content of protein in the feedstuffs, as protein is known to form insoluble complexes with phytic acid at low $\mathrm{pH}$ [69]. In support of this hypothesis it has been shown that phytic acid in SBM is much less soluble than phytic acid in maize meal at low $\mathrm{pH}$ (Figure 6). Furthermore, internal data produced at Novozymes A/S also show that treatment of a SBM-maize mixture with pepsin to degrade the protein fraction has a positive impact on phytic acid solubility (Figure 7). In the digestive tract endogenous digestive proteases will always be present to degrade protein and thereby improve the availability of phytic acid for hydrolysis by phytase. Supporting this there are a huge amount of in vivo studies demonstrating that phytases effectively releases phosphate in animals fed diets containing SBM e.g. Aureli et al. [70] showing phytase efficacy in broilers. 

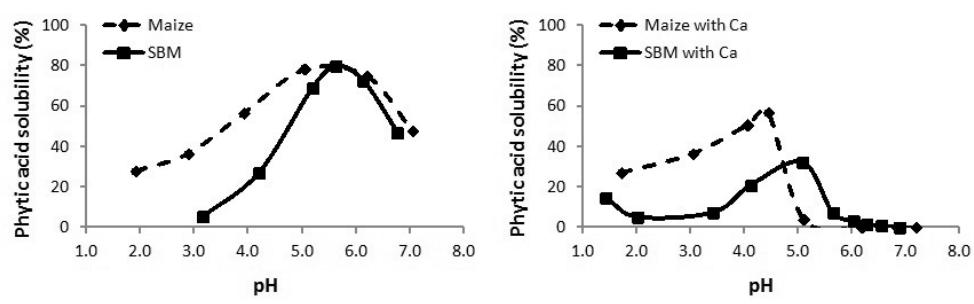

Figure 6. Phytic acid solubility (\%) in maize and SBM (left) and in maize and SBM with additional $5 \mathrm{~g}$ calcium kg-1 $\mathrm{dry}^{-}$ matter. Error bars represent standard deviations (2xSD) of 3 replicates. Modified from [71].

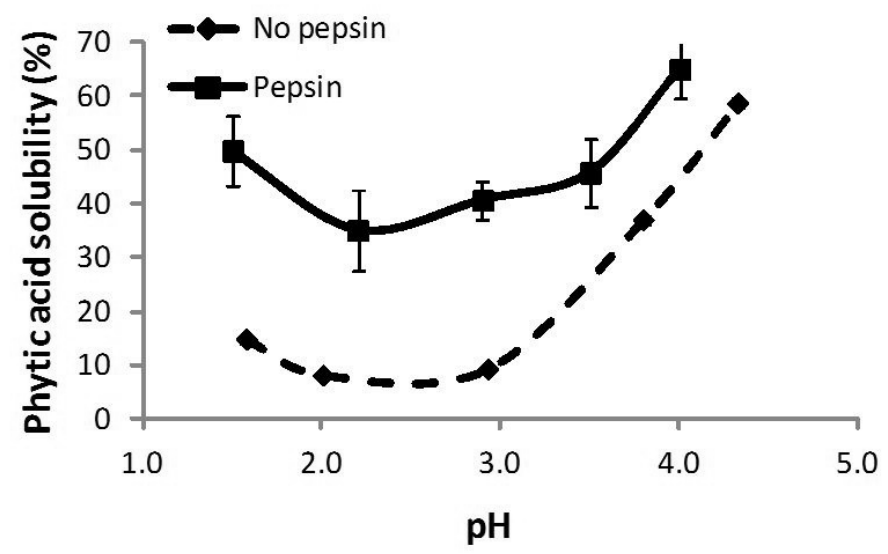

Figure 7. Phytic acid solubility (\%) in a SBM-maize (30:70) mixture with additional 5 mg calcium $\mathrm{g}^{-1}$ dry matter in the presence or absence of pepsin (3000 $\mathrm{U} \mathrm{g}^{-1}$ dry matter). Error bars represent standard deviations (2xSD) of 3 replicates. Unpublished data, Novozymes A/S.

\section{Conclusions}

SBM is the most important protein source in animal feed and it is estimated that approximately half of the SBM produced for animal feed is used in poultry diets, while another 25 $\%$ is used in pig diets. SBM is primarily added due to its high content of protein and favourable composition of AAs, while the low content of metabolisable energy and a high content of NSP may provide problems when incorporating this oil seed meal at high levels. The presence of several ANFs such as trypsin inhibitors and lectins may represent a severe problem that can restrict animal performance when feeding a meal that has not been properly processed, however there are indications that these short comings can be overcome by proper heat inactivation of the SBM as well as enzyme supplementation of the diet. 
Research results indicate that the nutritive value of SBM may be enhanced by adding exogenous microbial enzymes such as carbohydrate degrading enzymes, proteases and phytases. However, there is a need for improved carbohydrate degrading enzymes to better target the oligosaccharides of the raffinose series and also to reduce the negative effects of high levels of complex NSP constituents, that evidently are not degraded by common xylanases or $\mathrm{B}$ glucanases used for improving the feeding value of cereals.

The use of protease to improve protein digestibility and reduce the presence of anti nutritional proteins represents a novel and promising application that has an environmental impact by improving protein digestibility and thereby reducing nitrogen excretion from farm animals. In a similar way phytase supplementation is already a well established environmentally friendly application that reduces phosphorus excretion when feeding SBM rich in phytic acid.

\section{Author details}

D. Pettersson* and K. Pontoppidan

*Address all correspondence to: kpon@novozymes.com

Department of Feed Applications, Novozymes A/S, Denmark

\section{References}

[1] Soystats. (2012). http://www.soystats.com/2011/accessed 6 May).

[2] Bach, Knudsen. K. E. (1997). Carbohydrate and lignin contents of plant materials used in animal feeding. Animal Feed Science and Technology, 67-319.

[3] Sauvant, D., Perez-M, J., \& Tran, G. (2004). Tables of Composition and Nutitional Value of Feed Materials. INRA editions, Wageningen Publishers.

[4] Theander, O., Åman, P., Westerlund, E., Andersson, R., \& Pettersson, D. (1995). Total dietary fibre determined as neutral sugar residue, uronic acid residue and Klason lignin (The Uppsala Method): Collaborative study. Journal of AOAC International, 74-1030.

[5] Weier, E. T., Stocking, R. C., \& Barbour, M. G. (1970). Botany: An introduction to plant biology. New York: John Wiley E Sons Inc.

[6] Ravindran, V., Hew, L. I., \& Bryden, W. L. (1998). Digestible amino acids in poultry feedstuffs. Rural Industries Research \& Development Corporation, RIRDC publication [98].

[7] NRC. (1994). Nutrient requirements of poultry. $9^{\text {th }}$ revised edition. Washinton: National Academic Press. 
[8] Clarke, E., \& Wiseman, J. (2005). Effects of variability in trypsin inhibitor content of soja bean meals on true and apparent ileal digestibility of amino acids and pancreas size in broiler chicks. Animal Feed Science and Technology, 121-125.

[9] Hermida, M., Valencia, D. G., Serrano, M., \& Mateos, G. G. (2008). Influence of soybean meal origin on its nutritive value and quality parameters. Poultry Science, 87-29.

[10] De Coca-Sinova, A., Valencia, D. G., Jiménez-Moreno, E., Lázaro, R., \& Mateos, G. G. (2008). Apparent ileal digestibility of energy, nitrogen, and amino acids of soybean meals of different origin in broilers. Poultry Science, 87-2613.

[11] Minic, Z., \& Jouanin, L. (2006). Plant glycoside hydrolases involved in cell wall polysaccharide degradation. Plant Physiology and Biochemistry, 44-435.

[12] Huismann, M. M. H., Schols, H. A., \& Voragen, A. G. J. (1998). Cell wall polysaccharides from soybean (Glycine max) meal. Isolation and characterisation. Carbohydrate Polymers, 37-87.

[13] Siddiqui, R. I., \& Wood, P. J. (1977). Carbohydrates of rapeseed: a review. Journal of the Science of Food and Agriculture, 28-530.

[14] Mc Ginnis, J. (1983). Carbohydrate utilization in feedstuffs. In: Proceedings of the Minnesota nutrition conference, St. Paul, Minnesota, 106-107.

[15] Longstaff, M., \& Mc Nab, J. M. (1989). Digestion of fibre polysaccharides of pea (pisum sativum) hulls, carrot and cabbage by adult cockerels. British Journal of Nutrition, $62-563$.

[16] Carré, B., Derouet, L., \& Leclercq, B. (1990). The digestibility of cell wall polysaccharides from wheat (bran or whole grain), soya bean meal and white lupin meal in cockerels, Muscovy ducks and rats. Poultry Science, 69-623.

[17] Ishii, T. (1997). Structure and functions of feruloylated polysaccharides. Plant Science, 127-111.

[18] Mc Cann, M. C., \& Roberts, K. (1991). The cytoskeletal basis of plant growth and form. New York, USA: Academic Press.

[19] Carpita, N. C., \& Gibeaut, D. M. (1993). Structural models of primary cell walls in flowering plants: consistency of molecular structure with the physical properties of the walls during growth. Plant Journal, 3-1.

[20] Whitaker, J. R., Voragen, A. G. J., \& Wong, D. W. S. (2003). Handbook of food enzymology. New York, USA: Marcel Dekker.

[21] Warenham, C. N., Wiseman, J., \& Cole, D. J. A. (1994). Processing and antinutritive factors in feedstuff. In: Cole DJA, Wiseman J, Varley MA (eds.) Principles of Pig Science. Nottingham: Nottingham Press, 1, 141-167.

[22] Liener, I. E. (1989). Antinutritional factors. In: Matthews RH (ed.) Legumes: Chemistry, technology and human nutrition. New York: Marcel Dekker, 340-366. 
[23] Liener, I. E. (1989). Antinutritional factors in legume seeds: State of the art. In: Huisman J, van der Poel TFB, Liener IE (eds.) Recent Advances of Research in Antinutritional Factors in Grain Legume seeds: proceedings of the $1^{\text {st }}$ International Workshop on Antinutritional Factors in Legume Seeds, 13-25 November 1988, Wageningen, 6-13.

[24] Dongmo, T., Pone, D. K., \& Ngoupayou, J. D. N. (1989). Cottonseed cake in breeder hens diets: effects of supplementation with lysine and methionine. Archiv für Geflügelkunde, 53-231.

[25] Di Pietro, C. M., \& Liener, I. E. (1989). Heat inactivation of the Kunitz and BowmanBirk soybean protease inhibitors. Journal of Agricultural and Food Chemistry, 37, 39-44.

[26] Liener, I. E. (1994). Implications of antinutritional components in soybean foods. Critical Reviews in Food Science and Nutrition, 34-31.

[27] Sklan, D., Hurwitz, S., Budowski, P., \& Ascarelli, I. (1975). Fat digestion and absorption in chicks fed raw soy or heated soybean meal. Journal of Nutrition, 105-57.

[28] Grant, G., \& van Driessche, E. (1993). Legume lectins: physicochemical and nutritional properties. In : van Driessche E, van der Poel AFB, Huisman J, Saini HS (eds.) Recent advances of research in antinutritional factors in legume seeds. Wageningen, Netherlands: Wageningen Press, 219-233.

[29] Kennedy, J. F., Palva, P. M. G., Corella, M. T. S., Cavalcanti, M. S. M., \& Coelho, L. C. B. B. (1995). Lectins, versatile proteins of recognition: a review. Carbohydrate Polymers, 26-219.

[30] Schulze, H., Butts, C. A., Verstegen, M. W. A., Moughan, P. J., \& Huisman, J. (1995). Purified soybean lectins affect ileal nitrogen and amino acid flow in pigs. Proceedings of the 2nd European Conference on Grain Legumes, Copenhagen, 300-301.

[31] Kirchgessner, M., \& Windisch, W. (1995). Zum einfluss von mikrobieller phytase auf zootechnische leistungen und die verdauungsquotienten von phosphor, calcium, trockenmasse und stickstoff bei abgestufter Ca-versorgung in der ferkelaufzucht. $A g$ ribiological Research, 48-309.

[32] Selle, P. H., Ravindran, V., \& Caldwell, Bryden. W. L. (2000). Phytate and phytase: consequences for protein utilization. Nutrition Research Reviews, 13-255.

[33] Li, D. F., Nelssen, J. L., Reddy, P. G., Blecha, F., Klemm, R., \& Goodband, R. D. (1991). Interrelationship between hypersensitivity to soybean proteins and growth performance in early-weaned pigs. Journal of Animal Science, 69-4062.

[34] Snyder, H. E., \& Kwon, T. W. (1987). Processing of soybeans. In: Soybean utilization. New York, USA: Avi Book.

[35] Qin, G. X., Verstegen, M. W. A., \& Van der Poel, A. F. B. (1998). Effect of temperature and time during steam treatment on the protein quality of full-fat soybean meal from different origins. Journal of the Science of Food and Agriculture, 77-393. 
[36] Batal, A. B., Douglas, M. W., Engram, A. E., \& Parsons, C. M. (2000). Protein dispersibility index as an indicator of adequately processed soybean meal. Poultry Science, 79-1592.

[37] Araba, M., \& Dale, N. M. (1990). Evaluation of protein solubility as an indicator of overprocessing of soybean meal. Poultry Science, 69-76.

[38] Araba, M., \& Dale, N. M. (1990). Evaluation of protein solubility as an indicator of underprocessing of soybean meal. Poultry Science, 69-1749.

[39] Americal Oil Chemists Society. (2000). Official Methods and Recommended Practices. 5th edition. Urbana, IL: American Oil Chemists Society.

[40] Valencia, D. G., Serrano, M. P., Lázaro, R., Latorre, M. A., \& Mateos, G. G. (2008). Influence of micronization (fine grinding) of soya bean meal and full fat soya bean meal on productive performance and digestive traits in young pigs. Animal Feed Science and Technology, 147-340.

[41] Valencia, D. G., Serrano, M. P., Centeno, C., Lázaro, R., \& Mateos, G. G. (2008). Pea protein as a substitute of soya bean protein in diets for young pigs: Effects on productivity and digestive traits. Livestock Science, 188-1.

[42] Rackis, J. J., Mc Ghee, J. E., Liener, I. E., Kakade, M. L., \& Puski, G. (1974). Problems encountered in measuring trypsin inhibitor activity of soy flour. Report of a collaborative analysis. Cereal Science Today, 19-513.

[43] Peisker, M. (2001). Manufacturing of soy protein concentrate for animal nutrition. In: Brufau J. (ed.) Feed Manufactoring in the Mediterranean Region. Improving safety: From Feed to Food. Zaragoza, CIHEAM-IAMZ, Reus, Spain, 1036-1107.

[44] Nielsen, P. H., Dalgaard, R., Korsbak, A., \& Pettersson, D. (2008). Environmental assessment of digestibility improvement factors applied in animal production: Use of Ronozyme $^{\circledR}$ WX CT xylanase in Danish pig production. The International Journal of Life Cycle Assessment, 13-49.

[45] Nagaraju, R. K., \& Nielsen, P. H. (2011). Environmental advantages of phytase over inorganic phosphate in poultry feed. Poultry Punch, 27-57.

[46] Oxenböll, K. M., Pontoppidan, K., \& Nji-Fru, F. (2011). Use of a protease in poultry feed offers promising environmental benefits. International Journal of Poultry Science, $10-842$.

[47] Rooke, J. A., Slessor, M., Fraser, H., \& Thomson, J. R. (1998). Growth performance and gut function of piglets weaned at four weeks of age and fed protease-treated soya-bean meal. Animal Feed Science and Technology, 70-175.

[48] Ghazi, S., Rooke, J. A., Galbraith, H., \& Bedford, M. R. (2002). The potential for the improvement of the nutritive value of soya-bean meal by different proteases in broiler chicks and broiler cockerels. British Poultry Science, 43-70. 
[49] Bertechini, R. L., Carvalho, J. C. C., Mesquita, F. R., Castro, S. F., Meneghetti, C., \& Sorbara, J. O. B. (2009). Use of a protease to enhance the utilization of soybean meal amino acids by broilers. Poultry Science, 88(1), 69.

[50] Bertechini, R. L., Carvalho, J. C. C., Mesquita, F. R., Castro, S. F., Remolina, D. F., \& Sorbara, J. O. B. (2009). Use of a protease to enhance the utilization of full fat soybean amino acids by broilers. Poultry Science, 88(1), 70.

[51] Angel, C. R., Saylor, W., Vieira, S. L., \& Ward, N. (2011). Effects of a monocomponent protease on performance and protein utilization in 7- to 22-day-old broiler chickens. Poultry Science, 290-281.

[52] Freitas, D. M., Vieira, S. L., Angel, C. R., Favero, A., \& Maiorka, A. (2011). Performance and nutrient utilization of broilers fed diets supplemented with a novel monocomponent protease. Journal of Applied Poultry Research, 20-322.

[53] Fru-Nji, F., Kluenter, A. M., Fischer, M., \& Pontoppidan, K. (2011). A feed serine protease improves broiler performance and increases protein and energy digestibility. Journal of Poultry Science, 48-239.

[54] Pettersson, D., \& Åman, P. (1989). Enzyme supplementation of a poultry diet containing wheat and rye. British Journal of Nutrition, 62-139.

[55] Steenfeldt, S., \& Pettersson, D. (2001). Improvements in nutrient digestibility and performance of broiler chickens fed a wheat-and-rye based diet supplemented with enzymes. Journal of Animal Feed Science, 10-143.

[56] Slominski, B. A. (1994). Hydrolysis of galactooligosaccharides by commercial preparations of $\alpha$-galactosidase and $\beta$-fructofuranosidase: potential for use as dietary additives. Journal of the Science of Food and Agriculture, 65-323.

[57] Ao, T., Cantor, A. H., Pescatore, A. J., Pierce, J. L., \& Dawson, K. A. (2010). Effects of citric acid, alpha-galactosidase and protease inclusion on in vitro nutrient release from soybean meal and trypsin inhibitor content in raw whole soybeans. Animal Feed Science and Technology, 162-58.

[58] Leske, K. L., Jevne, C. J., \& Coon, C. N. (1993). Effect of oligosaccharide additions on nitrogen corrected true metabolizable energy of soy protein concentrate. Poultry Science, $72-664$.

[59] Leske, K. L., \& Coon, C. N. (1999). Nutrient content and energy digestibilities of ethanol-extracted, low $\alpha$-galactoside soybean meal as compared to intact soybean meal. Poultry Science, 78-1177.

[60] Coon, C. N., Leske, K. L., Akavanichan, O., \& Cheng, T. K. (1990). Effect of oligosaccharide-free soybean meal on true metabolizable energy and fiber digestion in adult roosters. Poultry Science, 69-787.

[61] Gdala, J., Johansen, H. N., Bach-Knudsen, K. E., Knap, I. H., Wagner, P., \& Joergensen, O. B. (1997). The digestibility of carbohydrates, protein, and fat in the small and 
large intestine of piglets fed non-supplemented and enzyme supplemented diets. $A n$ imal Feed Science and Technology, 65, 15-33.

[62] Graham, K. K., Kerley, M. S., Firman, J. D., \& Allee, G. L. (2002). The effect of enzyme treatment of soy-bean meal on oligosaccharide disappearance and chick growth performance. Poultry Science, 81, 1014-1019.

[63] Vahjen, W., Busch, T., \& Simon, O. (2005). Study on the use of soya bean polysaccharide degrading enzymes in broiler nutrition. Animal Feed Science and Technology, 120-259.

[64] Nelson, T. S., Ferrara, L. W., \& Storer, N. L. (1968). Phytate phosphorus content of feed ingredients derived from plants. Poultry Science, 47, 1372-1374.

[65] Eeckhout, W., \& De Paepe, M. (1994). Total phosphorus, phytate phosphorus and phytase activity in plant feedstuffs. Animal Feed Science and Technology, 47-19.

[66] Ravindran, V., Ravindran, G., \& Sivalogan, S. (1994). Total and phytate phosphorus contents of various foods and feedstuffs of plant origin. Food Chemistry, 50-133.

[67] Jongbloed, A. W., \& Kemme, P. A. (1990). Effect of pelleting mixed feeds on phytase activity and the apparent absorbability of phosphorus and calcium in pigs. Animal Feed Science and Technology, 28, 233-242.

[68] Brejnholt, S. M., Dionisio, G., Glitsoe, V., Skov, L. K., \& Brinch-Pedersen, H. (2011). The degradation of phytate by microbial and wheat phytases is dependent on the phytate matrix and the phytase origin. Journal of the Science of Food and Agriculture, 91-1398.

[69] Hill, R., \& Tyler, C. (1954). The reaction between phytate and protein. Journal of Agricultural Science, 44-324.

[70] Aureli, R., Umar, Faruk. M., Cechova, I., Pedersen, P. B., Elvig-Joergensen, S. G., Fru, F., \& Broz, J. (2011). The efficacy of a novel microbial 6-phytase expressed in Aspergillus oryzae on the performance and phosphorus utilization in broiler chickens. International Journal of Poultry Science, 10, 160-168.

[71] Pontoppidan, K. (2009). Factors influencing phytate degradation in piglets: feed phytate behaviour and degradation by microbial phytases. PhD thesis. Department of Chemical and Biological Engineering Chalmers University of Technology Göteborg Sweden. 
